\title{
Mechanisms of Lithium Intercalation and Conversion Processes in Organic-Inorganic Halide Perovskites
}

\author{
James A. Dawson, ${ }^{*}{ }^{\dagger}$ Andrew J. Naylor, ${ }^{\ddagger}$ Christopher Eames, ${ }^{\dagger}{ }^{\dagger}$ Matthew Roberts, ${ }^{\ddagger}$ Wei Zhang, ${ }^{\S}$ \\ Henry J. Snaith," Peter G. Bruce, ${ }^{\ddagger}$ and M. Saiful Islam* ${ }^{* \dagger}$
}

${ }^{\dagger}$ Department of Chemistry, University of Bath, Bath BA2 7AY, United Kingdom

${ }^{\ddagger}$ Department of Materials, University of Oxford, Oxford OX1 3PH, United Kingdom

${ }^{\S}$ Advanced Technology Institute, University of Surrey, Guildford GU2 7XH, United Kingdom

"Clarendon Laboratory, Department of Physics, University of Oxford, Oxford OX1 3PU, United Kingdom

Supporting Information

\begin{abstract}
Organic-inorganic halide perovskites are attracting extraordinary attention in the field of energy materials. The reaction of hybrid lead halide perovskites with $\mathrm{Li}$ metal has recently been proposed for a number of potential applications. However, the mechanisms for $\mathrm{Li}$ uptake in such materials, such as intercalation and conversion, are still unknown. Using a combination of density functional theory and electrochemical and diffraction techniques, we consider $\mathrm{Li}$ intercalation and conversion reactions in $\mathrm{CH}_{3} \mathrm{NH}_{3} \mathrm{PbI}_{3}, \mathrm{CH}_{3} \mathrm{NH}_{3} \mathrm{PbBr}_{3}$, and $\mathrm{CH}_{3} \mathrm{NH}_{3} \mathrm{PbCl}_{3}$. Our simulations suggest that conversion reactions with $\mathrm{Li}$ are far more energetically preferable in these materials than $\mathrm{Li}$ intercalation. Calculations confirm the formation of $\mathrm{Pb}$ metal as a result of $\mathrm{Li}$ conversion in all three materials, and this is supported by $\mathrm{X}$-ray diffraction analysis of $\mathrm{CH}_{3} \mathrm{NH}_{3} \mathrm{PbBr}_{3}$. The results of this study provide fresh insights into lithium and halide perovskite reactions that will hopefully drive further exploration of these materials for a wider variety of energy applications.

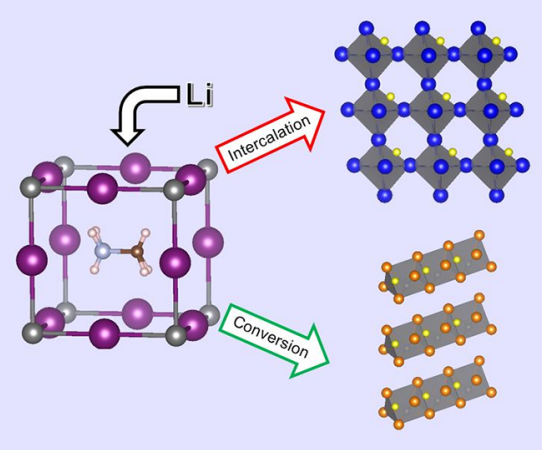

$\mathrm{H}$ ybrid lead halide perovskites are currently attracting remarkable attention in the field of photovoltaics because of their high solar-to-electricity conversion efficiencies. ${ }^{1-4}$ As a result of the combination of their organic and inorganic constituents, these materials are structurally versatile, can be processed at low temperatures, and have properties that can be tuned accordingly for the desired application. However, their stability remains an issue, although recent reports of mixed-cation perovskites are very encouraging for technical use. ${ }^{5,6}$

The majority of research involving hybrid perovskites has been devoted to methylammonium lead halides, $\mathrm{CH}_{3} \mathrm{NH}_{3} \mathrm{PbX}_{3}$, where $\mathrm{X}=\mathrm{I}, \mathrm{Br}$, or $\mathrm{Cl}^{7-15}$ The structure of these halide perovskites is a three-dimensional framework of corner-sharing $\mathrm{PbX}_{6}$ octahedra with organic methylammonium cations $\left(\mathrm{CH}_{3} \mathrm{NH}_{3}^{+}\right)$occupying the central A-site of the standard $\mathrm{ABX}_{3}$ perovskite structure.

The use of organic-inorganic hybrid perovskites in Li-ion battery applications has only recently been proposed. Xia et al. ${ }^{16}$ used a hydrothermal method to prepare $\mathrm{CH}_{3} \mathrm{NH}_{3} \mathrm{PbBr}_{3}$ and $\mathrm{CH}_{3} \mathrm{NH}_{3} \mathrm{PbI}_{3}$ for use as anode materials in Li-ion batteries. They reported good electrochemical performance for
$\mathrm{CH}_{3} \mathrm{NH}_{3} \mathrm{PbBr}_{3}$ with a first discharge capacity of $331.8 \mathrm{~mA} \mathrm{~h}$ $\mathrm{g}^{-1}$ at a current density of $200 \mathrm{~mA} \mathrm{~g}^{-1}$. This capacity is approximately equal to that of commercially available graphite. The material has a density of $3.93 \mathrm{~g} \mathrm{~cm}^{-3}$, which is almost double that of commercially available graphite, indicating significant potential volumetric energy density gains. However, despite these striking performance metrics, the mechanism through which this is achieved remains unclear, as also noted by Smith et al. ${ }^{17}$ The high first discharge capacity is approximatively six times the maximum theoretical capacity for $\mathrm{CH}_{3} \mathrm{NH}_{3} \mathrm{PbBr}_{3}\left(55.96 \mathrm{~mA} \mathrm{~h} \mathrm{~g}^{-1}\right)$, if it is assumed that one lithium ion could intercalate per formula unit. These results suggest that a conversion reaction or another effect is taking place because six intercalating $\mathrm{Li}$ ions per formula unit would be required otherwise. The results for $\mathrm{CH}_{3} \mathrm{NH}_{3} \mathrm{PbI}_{3}$ were less encouraging with a first discharge capacity of $43.6 \mathrm{~mA} \mathrm{~h} \mathrm{~g}^{-1}$ at a current density of $200 \mathrm{~mA} \mathrm{~g}$. The reasons for these

Received: May 23, 2017

Accepted: July 14, 2017

Published: July 14, 2017 
dramatically different electrochemical performances, however, were not explained, and no mechanistic details for Li uptake in the materials were provided. ${ }^{16}$

More recently, $\mathrm{Li}$ intercalation into $\mathrm{CH}_{3} \mathrm{NH}_{3} \mathrm{PbBr}_{3}$ has been reported, ${ }^{18}$ with insertion of a high Li-ion molar concentration of almost three, without drastic structural alterations. It is unclear what species is reduced as a result of $\mathrm{Li}$ intercalation given that the $\mathrm{Pb}$ and $\mathrm{Br}$ electronic structures remain mostly unchanged and the cell assembly was carried out in a $\mathrm{N}_{2}$-filled glovebox.

In addition, a two-dimensional hybrid halide perovskite $\left(\left(2,2^{\prime}\right.\right.$-(ethylenedioxy)bis(ethylammonium) $\left.\left[\mathrm{CuCl}_{4}\right]\right)$ was recently proposed as a cathode material for Li-ion cycling, ${ }^{19}$ showing an open-circuit voltage of $3.2 \mathrm{~V}$. It was proposed that the electrochemical behavior of the system was consistent with either a conversion reaction, an intercalation mechanism, or a mixture of the two. ${ }^{19}$ Jiang et al. ${ }^{20}$ reported electrochemical ntype doping of the inorganic halide perovskite, $\mathrm{CsPbBr}_{3}$, through Li-ion intercalation. Previous work on Li-based perovskites is dominated by the $(\mathrm{Li}, \mathrm{La}) \mathrm{TiO}_{3}$ electrolyte system, $^{21,22}$ which shows significant levels of A-site deficiency.

The impressive reported electrochemical performance, despite a poorly established reaction pathway, highlights the need for an in-depth study focused on these materials. In order to ascertain the $\mathrm{Li}$ uptake mechanisms and the reasons behind the different electrochemical performances reported for hybrid halide perovskites, we use a combination of first-principles, electrochemical, and powder X-ray diffraction (PXRD) techniques to investigate $\mathrm{CH}_{3} \mathrm{NH}_{3} \mathrm{PbX}_{3}$, where $\mathrm{X}=\mathrm{I}, \mathrm{Br}$, or $\mathrm{Cl}$. First-principles methods are well established in calculating a wide variety of electronic, structural, and defect properties of Li-ion battery materials ${ }^{23-28}$ and hybrid halide perovskites. ${ }^{29-36}$ Our simulations show that the conversion process to lithium halides $(\mathrm{LiX})$ and $\mathrm{Pb}$ metal dominates, particularly for $\mathrm{CH}_{3} \mathrm{NH}_{3} \mathrm{PbBr}_{3}$ and $\mathrm{CH}_{3} \mathrm{NH}_{3} \mathrm{PbCl}_{3}$. These findings are also supported by electrochemical measurements and PXRD. Our results help to rationalize why the electrochemical performance of $\mathrm{CH}_{3} \mathrm{NH}_{3} \mathrm{PbI}_{3}$ is poor and highlight possible reasons for any differences between the three hybrid perovskites considered.

With regard to our methods, all calculations were carried out using density functional theory (DFT) with the ab initio code VASP. ${ }^{37}$ A plane-wave cutoff energy of $500 \mathrm{eV}$, the projector augmented wave method, ${ }^{38}$ and the PBEsol exchangecorrelation functional were employed. This functional was chosen as it is considered a highly accurate GGA functional for solids, as shown by its use in many previous successful studies of hybrid perovskites for a wide variety of properties. ${ }^{30-32,35,36}$

As can be seen from Table 1, the PBEsol functional accurately reproduces the experimental crystal structures, ${ }^{39}$

Table 1. Lattice Parameters of Cubic $\mathrm{CH}_{3} \mathrm{NH}_{3} \mathrm{PbX}_{3}$ (where $\mathrm{X}=\mathrm{I}, \mathrm{Br}$, or $\mathrm{Cl}$ )

\begin{tabular}{ccc}
\hline system & DFT (this work) $(\AA)$ & experiment $(\AA)^{39}$ \\
$\mathrm{CH}_{3} \mathrm{NH}_{3} \mathrm{PbI}_{3}$ & 6.282 & 6.276 \\
$\mathrm{CH}_{3} \mathrm{NH}_{3} \mathrm{PbBr}_{3}$ & 5.914 & 5.931 \\
$\mathrm{CH}_{3} \mathrm{NH}_{3} \mathrm{PbCl}_{3}$ & 5.663 & 5.684 \\
\hline
\end{tabular}

with differences of less than $0.4 \%$. In particular, the lattice parameter for $\mathrm{CH}_{3} \mathrm{NH}_{3} \mathrm{PbI}_{3}$ is in excellent agreement with neutron diffraction studies, with a difference of $<0.1 \%$. As we do not expect the fundamental trends presented in this work to significantly differ for the tetragonal and orthorhombic hybrid perovskite structures, we believe that our choice of the cubic phase as a representative structure is fully valid. The majority of computational studies of these materials in the literature have focused on the cubic phase. Further details of the modeling of $\mathrm{CH}_{3} \mathrm{NH}_{3} \mathrm{PbX}_{3}$ phases are available elsewhere. ${ }^{40-42}$

Using well-established methodology, the calculation of $\mathrm{Li}$ intercalation sites and voltages by DFT has been achieved for a wide variety of Li-ion battery materials. ${ }^{23-27}$ Details of the voltage calculations are available in the SI.

It is well-known that the $\mathrm{CH}_{3} \mathrm{NH}_{3}{ }^{+}$cation can freely rotate in cubic $\mathrm{CH}_{3} \mathrm{NH}_{3} \mathrm{PbI}_{3}$, ${ }^{43}$ and DFT calculations have shown that the energy barriers for rotation are low. ${ }^{35}$ In addition, ab initio molecular dynamics showed a preference for the $\langle 100\rangle$ facial configuration at $300 \mathrm{~K}^{36}$ We therefore chose this configuration for the calculations in this study. Nevertheless, we note that DFT studies have reported that the $\mathrm{CH}_{3} \mathrm{NH}_{3}{ }^{+}$orientation can have an effect on the band structure properties for these materials. ${ }^{44}$ Therefore, we carried out preliminary calculations of the effects of $\mathrm{CH}_{3} \mathrm{NH}_{3}{ }^{+}$orientation using a $2 \times 1 \times 1$ $\mathrm{CH}_{3} \mathrm{NH}_{3} \mathrm{PbI}_{3}$ supercell with one $\mathrm{Li}$ ion, equivalent to $\mathrm{Li}_{0.5} \mathrm{CH}_{3} \mathrm{NH}_{3} \mathrm{PbI}_{3}$. The results are presented in Table S2. It is discovered that there is little difference between the intercalation voltages for the three primary orientations, $\langle 100\rangle$ (face), $\langle 110\rangle$ (edge), and $\langle 111\rangle$ (diagonal) (Figure $\mathrm{S} 1)$. The relatively small differences between the values $(<0.1$ $\mathrm{eV})$ for different organic cation orientations justifies our approach in focusing on the $\langle 100\rangle$ orientation.

The $\mathrm{CH}_{3} \mathrm{NH}_{3} \mathrm{PbBr}_{3}$ single crystals were synthesized following the literature report. ${ }^{45} \mathrm{~A} 1 \mathrm{M}$ solution containing lead bromide ( $\geq 98 \%$, Sigma-Aldrich) and methylammonium bromide (MABr, Dyesol Limited) was prepared in anhydrous DMF (99.8\%, Sigma-Aldrich). The solution was prepared at room temperature and was filtered using a PTFE filter with 0.2 $\mu \mathrm{m}$ pore size. The filtrate $(20 \mathrm{~mL})$ was placed in a $60 \mathrm{~mL}$ glass jar, and the jar was kept in an oil bath undisturbed at $90^{\circ} \mathrm{C}$. The crystals were typically grown for $8-12 \mathrm{~h}$. All procedures were carried out under ambient conditions. Further details on the synthesis and electrochemical testing are given in the SI.

PXRD patterns of the pristine and discharged electrodes were acquired on a Rigaku SmartLab X-ray diffractometer with $\mathrm{Cu} \mathrm{K} \alpha$ radiation $(\lambda=1.5406 \AA)$, with samples mounted in a protective-atmosphere sample holder (Kapton window, loaded in an argon-filled glovebox). The XRD measurements were carried out at room temperature.

In terms of our intercalation study, to the best of our knowledge, $\mathrm{Li}$ insertion in $\mathrm{CH}_{3} \mathrm{NH}_{3} \mathrm{PbX}_{3}$ has only once been previously considered; ${ }^{16}$ however, no details on the $\mathrm{Li}$ concentrations in the samples or the $\mathrm{Li}$ uptake mechanism were given. Nevertheless, the cyclic voltammetry experiments suggest that the main oxidation/reduction processes in the $\mathrm{CH}_{3} \mathrm{NH}_{3} \mathrm{PbI}_{3}$ and $\mathrm{CH}_{3} \mathrm{NH}_{3} \mathrm{PbBr}_{3}$ anodes occur at $\sim 0.5-0.7 \mathrm{~V}$. In this study, we simulate four primary $\mathrm{Li}$ concentrations, namely, $x=0.037,0.125,0.5$, and 1.0 in $\mathrm{Li}_{x} \mathrm{CH}_{3} \mathrm{NH}_{3} \mathrm{PbX}_{3}$, where $x=1.0$ represents full $\mathrm{Li}$ intercalation. $\mathrm{Li}$ was inserted at all possible octahedral and tetrahedral sites (illustrated in Figure 1) in order to find the lowest-energy (most stable) intercalation sites. The calculated intercalation voltages for the lowest-energy Li-intercalated octahedral and tetrahedral sites in each material and at each concentration are listed in Table 2.

The results presented in Table 2 indicate three main features. First, our calculated voltages for Li concentrations of $x \leq 0.125$ are in good agreement with the observed values for the $\mathrm{Li}_{x} \mathrm{CH}_{3} \mathrm{NH}_{3} \mathrm{PbBr}_{3}$ anode reported at around $0.5-0.7 \mathrm{~V}{ }^{16}$ The 

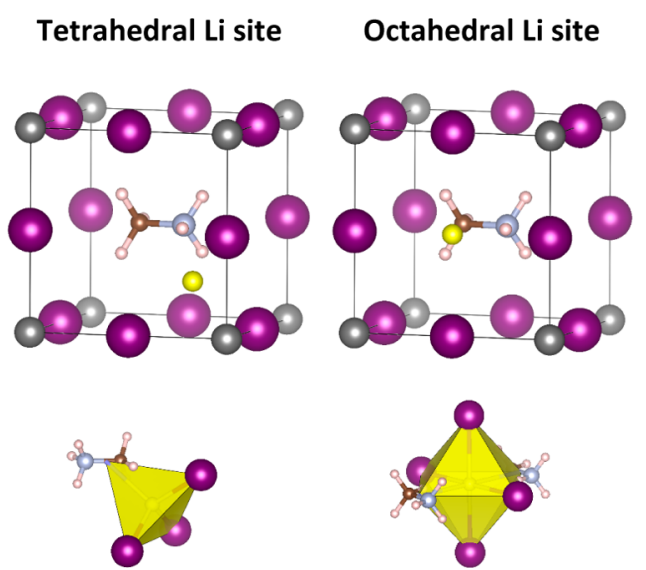

Figure 1. Cubic perovskite structures of $\mathrm{CH}_{3} \mathrm{NH}_{3} \mathrm{PbI}_{3}$ illustrating the two main $\mathrm{Li}$ intercalation sites. $\mathrm{CH}_{3} \mathrm{NH}_{3}{ }^{+}$occupies the central A-site surrounded by 12 nearest-neighbor halide ions (purple). $\mathbf{P b}$ ions are gray. The yellow spheres indicate the tetrahedral and octahedral $\mathrm{Li}$ intercalation sites. The local coordination environments of the $\mathrm{Li}^{+}$ions are also displayed.

site preference and intercalation voltage are strongly dependent on both the material and $\mathrm{Li}$ concentration.

Second, at low $\mathrm{Li}$ concentrations, insertion into $\mathrm{CH}_{3} \mathrm{NH}_{3} \mathrm{PbI}_{3}$ becomes more favorable than that for the other perovskites, in agreement with basic lattice volume arguments. Inserting $\mathrm{Li}$ into the larger $\mathrm{CH}_{3} \mathrm{NH}_{3} \mathrm{PbI}_{3}$ unit cell causes less distortion to the $\mathrm{PbI}_{6}$ octahedra because of the larger $\mathrm{Pb}-\mathrm{Li}$ interatomic distances than that for the equivalent octahedra in $\mathrm{CH}_{3} \mathrm{NH}_{3} \mathrm{PbBr}_{3}$ and $\mathrm{CH}_{3} \mathrm{NH}_{3} \mathrm{PbCl}_{3}$.

Third, at full $\mathrm{Li}$ intercalation $(x=1.0)$, the $\mathrm{PbX}_{6}$ octahedra undergo structural distortion in all three of the materials, with the distortion being particularly pronounced in $\mathrm{CH}_{3} \mathrm{NH}_{3} \mathrm{PbBr}_{3}$ and $\mathrm{CH}_{3} \mathrm{NH}_{3} \mathrm{PbCl}_{3}$. The structures of the unit cells change dramatically during optimization, as illustrated in Figure 2, possibly indicating the existence of conversion or decomposition reactions when approaching full $\mathrm{Li}$ intercalation, a point that we return to below. The interatomic distances for the $\mathrm{Li}$ octahedra in these optimized structures are given in Table S3. These octahedra are also significantly distorted, leading to large distances between the intercalating $\mathrm{Li}^{+}$ions and organic cations.

The influence of these dramatic structural changes can be further elaborated by fixing the cell geometries of the fully intercalated structures. For $\mathrm{CH}_{3} \mathrm{NH}_{3} \mathrm{PbI}_{3}, \mathrm{CH}_{3} \mathrm{NH}_{3} \mathrm{PbBr}_{3}$, and $\mathrm{CH}_{3} \mathrm{NH}_{3} \mathrm{PbCl}_{3}$, the intercalation voltages for $x=1.0$ at the lowest-energy octahedral sites, are $-0.19,-0.51$, and $-0.39 \mathrm{~V}$, respectively, for fixed-cell geometry optimizations. These negative voltages clearly illustrate the difficulty in inserting
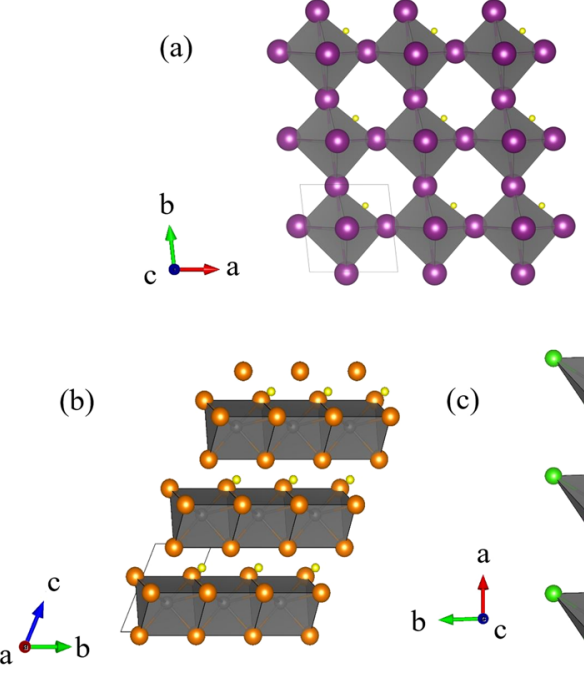

(c)
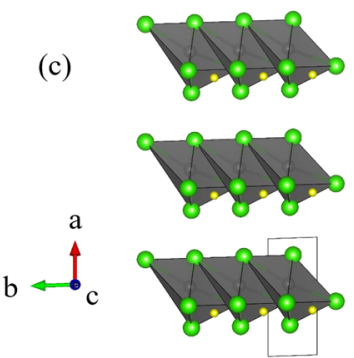

Figure 2. Optimized structures of $\mathrm{LiCH}_{3} \mathrm{NH}_{3} \mathrm{PbX}_{3}$ based on $3 \times 3$ $\times 1$ replicated unit cell structures with the $\mathrm{Li}$ ions placed at octahedral sites. (a) $\mathrm{LiCH}_{3} \mathrm{NH}_{3} \mathrm{PbI}_{3}$, (b) $\mathrm{LiCH}_{3} \mathrm{NH}_{3} \mathrm{PbBr}_{3}$, and (c) $\mathrm{LiCH}_{3} \mathrm{NH}_{3} \mathrm{PbCl}_{3} \cdot \mathrm{CH}_{3} \mathrm{NH}_{3}{ }^{+}$cations have been omitted for clarity. $\mathrm{PbX}_{6}$ octahedra (gray) are formed using the six closest anions to the central $\mathrm{Pb}^{2+}$ ions. $\mathrm{I}^{-}, \mathrm{Br}^{-}, \mathrm{Cl}^{-}$, and $\mathrm{Li}^{+}$ions are shown by the purple, orange, green, and yellow spheres, respectively. The black lines indicate the unit cell structures.

high concentrations of $\mathrm{Li}$ into these materials when structural distortion and rearrangement are not allowed.

Further evidence for a conversion process in these materials at $x=1.0$ can be found by examining the relaxed unit cell structures in Figure 2. By extending the $\mathrm{LiCH}_{3} \mathrm{NH}_{3} \mathrm{PbBr}_{3}$ and $\mathrm{LiCH}_{3} \mathrm{NH}_{3} \mathrm{PbCl}_{3}$ unit cells in three dimensions, we see the formation of layered-like materials as a result of the $\mathrm{PbX}_{6}$ octahedra effectively being pulled apart by the inclusion of $\mathrm{Li}$. In the case of $\mathrm{LiCH}_{3} \mathrm{NH}_{3} \mathrm{PbBr}_{3}$, the $\mathrm{Li}$ ions occupy sites between the $\mathrm{PbBr}_{6}$ octahedra layers that are tetrahedrally coordinated to $\mathrm{Br}$ ions. For $\mathrm{LiCH}_{3} \mathrm{NH}_{3} \mathrm{PbCl}_{3}$, the $\mathrm{Li}$ ions are in square-planar-like arrangements, coordinated to four $\mathrm{Cl}$ ions. While $\mathrm{LiCH}_{3} \mathrm{NH}_{3} \mathrm{PbI}_{3}$ is also distorted, it is to a far lesser extent than the other two structures, with the cubic structure mostly retained. These results illustrate the potential of layered twodimensional perovskites as Li-ion battery materials, as noted previously. ${ }^{1,16}$ Details regarding the $\mathrm{CH}_{3} \mathrm{NH}_{3}{ }^{+}$orientation and $\mathrm{Li}$ polyhedra in these intercalated materials are available in Figure S2 and Table S3.

In order to identify the character of the reduced species in $\mathrm{CH}_{3} \mathrm{NH}_{3} \mathrm{PbX}_{3}$ as a result of $\mathrm{Li}$ intercalation, we carried out analysis of the Bader charge ${ }^{46}$ from the DFT calculations. Bader analysis has been used to investigate the $\mathrm{Li}$ intercalation behavior of a number of cathode and anode materials. ${ }^{47,48}$ The

Table 2. Li Intercalation Voltages (V) for the Lowest-Energy Octahedral (Oct) and Tetrahedral (Tet) $\mathrm{Sites}_{\text {in }} \mathrm{Li}_{x} \mathrm{CH}_{3} \mathrm{NH}_{3} \mathrm{PbX}_{3}$ (where $\mathrm{X}=\mathrm{I}, \mathrm{Br}$, or $\mathrm{Cl}$ )

\begin{tabular}{|c|c|c|c|c|c|c|c|c|}
\hline \multirow[b]{2}{*}{ system } & \multicolumn{2}{|c|}{$x \mathrm{Li}=0.037$} & \multicolumn{2}{|c|}{$x \mathrm{Li}=0.125$} & \multicolumn{2}{|c|}{$x \mathrm{Li}=0.5$} & \multicolumn{2}{|c|}{$x \mathrm{Li}=1.0$} \\
\hline & Oct & Tet & Oct & Tet & Oct & Tet & Oct & Tet \\
\hline $\mathrm{CH}_{3} \mathrm{NH}_{3} \mathrm{PbI}_{3}$ & 1.44 & 1.40 & 1.36 & 1.43 & 0.25 & 0.20 & 0.13 & 0.00 \\
\hline $\mathrm{CH}_{3} \mathrm{NH}_{3} \mathrm{PbBr}_{3}$ & 0.57 & 0.84 & 0.45 & 0.81 & 0.12 & 0.16 & $\mathrm{SR}^{a}$ & $\mathrm{SR}^{a}$ \\
\hline $\mathrm{CH}_{3} \mathrm{NH}_{3} \mathrm{PbCl}_{3}$ & 0.31 & 0.59 & 0.27 & 0.52 & 0.18 & 0.16 & $\mathrm{SR}^{a}$ & $\mathrm{SR}^{a}$ \\
\hline
\end{tabular}

${ }^{a} \mathrm{SR}$ : $\mathrm{LiCH}_{3} \mathrm{NH}_{3} \mathrm{PbBr}_{3}$ and $\mathrm{LiCH}_{3} \mathrm{NH}_{3} \mathrm{PbCl}_{3}$ exhibited significant structural rearrangement and disorder during geometry optimization, leading to unrealistic intercalation voltages. 
percentage changes in Bader partial charges after full $\mathrm{Li}$ intercalation $(x \mathrm{Li}=1.0)$ are given for the lowest-energy octahedral site in Figure 3. In all three materials, the majority of

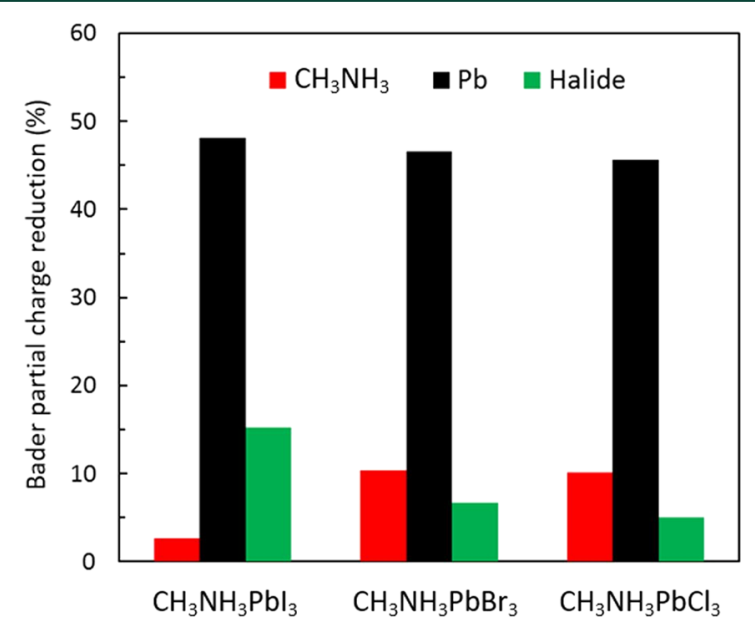

Figure 3. Percentage change in Bader partial charges after $\mathrm{Li}$ intercalation $(x \mathrm{Li}=1.0)$ for the three component species in $\mathrm{CH}_{3} \mathrm{NH}_{3} \mathrm{PbX}_{3}$.

excess charge from $\mathrm{Li}$ intercalation is localized on a $\mathrm{Pb}$ cation. After the insertion of $\mathrm{Li}$, the partial charge of the neighboring $\mathrm{Pb}$ is approximately halved, suggesting the existence of $\mathrm{Pb}^{+}$ions in these intercalated systems. Similar results were also seen for the tetrahedral sites and for different $\mathrm{Li}$ concentrations. In addition, spin-orbit coupling (SOC) and van der Waals (vdW) effects were also tested in order to examine their influence on the Bader charge partitioning in $\mathrm{LiCH}_{3} \mathrm{NH}_{3} \mathrm{PbBr}_{3}$, with the results presented in Tables S4-S6. It is clear that while these effects have some influence on the Bader charge analysis, they still show the reduction of $\mathrm{Pb}$ as a result of $\mathrm{Li}$ intercalation.

To help clarify whether $\mathrm{Li}$ intercalation or conversion is dominant in these systems, we carried out electrochemical characterization of $\mathrm{CH}_{3} \mathrm{NH}_{3} \mathrm{PbBr}_{3}$ because this representative system showed the highest discharge capacity. Figure 4 shows the first discharge profile for a $\mathrm{CH}_{3} \mathrm{NH}_{3} \mathrm{PbBr}_{3}$ perovskite electrode from the open-circuit voltage for the cell to $0.1 \mathrm{~V}$, at a rate of $20 \mathrm{~mA} \mathrm{~g}^{-1}$. A specific capacity for discharge of $134.3 \mathrm{~mA}$ $\mathrm{h} \mathrm{g}^{-1}$ is obtained.

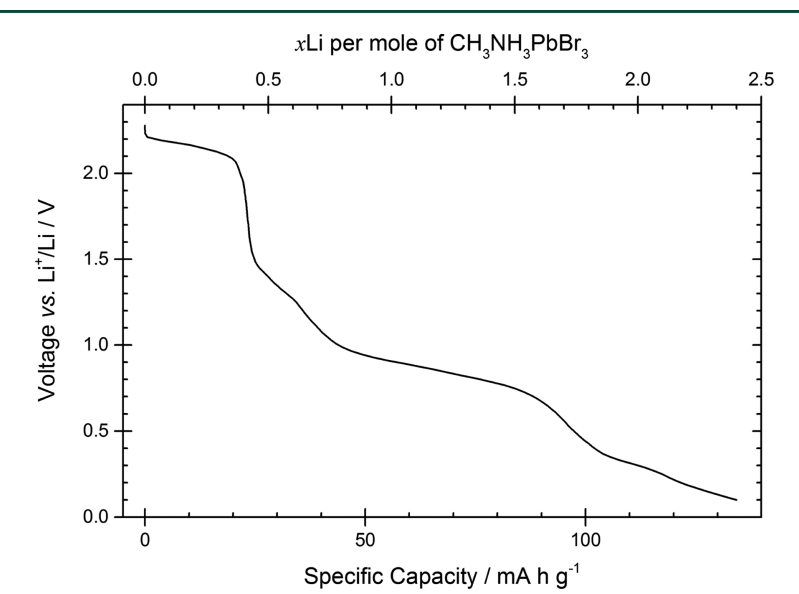

Figure 4. First discharge profile for a $\mathrm{CH}_{3} \mathrm{NH}_{3} \mathrm{PbBr}_{3}$ perovskite electrode.
The charge passed during the first discharge corresponds to $2.4 \mathrm{Li}^{+}$ions per mole of $\mathrm{CH}_{3} \mathrm{NH}_{3} \mathrm{PbBr}_{3}$, which is beyond the 1 vacant site per mol limit available in pristine $\mathrm{CH}_{3} \mathrm{NH}_{3} \mathrm{PbBr}_{3}$ necessary for an intercalation mechanism. Furthermore, the capacity observed below $1 \mathrm{~V}$ may contain a significant contribution from electrolyte reduction to form a solid electrolyte interphase (SEI) layer on the electrode. ${ }^{49}$ Therefore, we cannot draw a definitive conclusion as to the charge compensation mechanism from the electrochemistry data.

To help elucidate the mechanism, PXRD patterns were collected for $\mathrm{CH}_{3} \mathrm{NH}_{3} \mathrm{PbBr}_{3}$ electrodes discharged to different voltages (Figure 5). For the pristine electrode, all peaks except

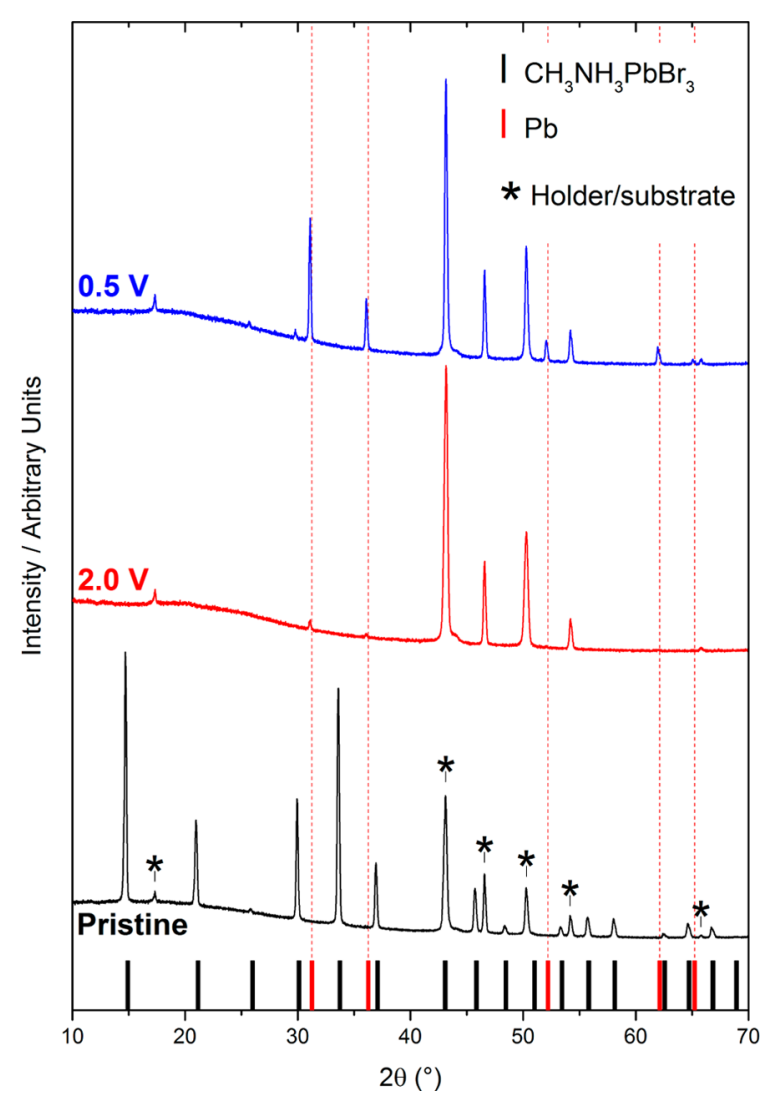

Figure 5. PXRD patterns of the pristine composite $\mathrm{CH}_{3} \mathrm{NH}_{3} \mathrm{PbBr}_{3}$ electrode discharged to 2.0 and $0.5 \mathrm{~V}$. The $\mathrm{CH}_{3} \mathrm{NH}_{3} \mathrm{PbBr}_{3}$ can be indexed on the cubic perovskite structure (space group $P m 3 m$ and $a=5.933 \AA$ ) shown by black bars. ${ }^{50} \mathrm{~Pb}$ peaks (space group $F m \overline{3} m$ and $a=4.951 \AA$ ) are shown by red bars.

for those corresponding to the sample holder and $\mathrm{Cu}$ current collector can be indexed on the $\mathrm{CH}_{3} \mathrm{NH}_{3} \mathrm{PbBr}_{3}$ space group $(P m \overline{3} m, a=5.9328 \AA) .{ }^{50}$ The broad amorphous region in all patterns can be attributed to the Kapton film on the sample holder and residual glass fiber separator from the cell. For the electrode discharged to $2 \mathrm{~V}$, the $\mathrm{CH}_{3} \mathrm{NH}_{3} \mathrm{PbBr}_{3}$ peaks are no longer present, while some new small peaks (31.2 and $36.3^{\circ}$ ) are observed that can be closely matched to $\mathrm{Pb}$ metal (space group $F m \overline{3} m, a=4.951 \AA) .{ }^{51}$ The intensity of these peaks increases for the electrodes discharged to $0.5 \mathrm{~V}$, with the addition of further peaks attributable to $\mathrm{Pb}(52.2,62.1$, and $\left.65.2^{\circ}\right)$. The growth of the $\mathrm{Pb}$ peak intensities suggests that if SEI film formation takes place at voltages below $\sim 1 \mathrm{~V}$, it occurs alongside further conversion to form $\mathrm{Pb}$. We cannot assign any other possible conversion/decomposition reaction species (e.g., 
$\mathrm{PbBr}_{2}, \mathrm{CH}_{3} \mathrm{NH}_{3} \mathrm{Br}$, and $\mathrm{LiBr}$ ) to the PXRD patterns. Moreover, these are likely to be soluble in the electrolyte, in which case they would not be observed as a product on the electrode. In any case, bromide perovskite peaks are no longer present, and new $\mathrm{Pb}$ metal peaks are observed.

One of the major challenges facing organic-inorganic halide perovskites in commercial applications is their stability. Experiments have shown that moisture, oxygen, ultraviolet radiation, and heat all have an effect on the degradation of these materials, and various decomposition reaction pathways have been proposed in recent years. ${ }^{32,52-56}$ In addition to the reported finding that the measured capacity of $\mathrm{CH}_{3} \mathrm{NH}_{3} \mathrm{PbBr}_{3}$ far exceeds the maximum theoretical capacity ${ }^{16}$ and the formation of layered structures discussed above, we have examined possible conversion reactions for $\mathrm{Li}$ and $\mathrm{CH}_{3} \mathrm{NH}_{3} \mathrm{PbX}_{3}$ using the fundamental decomposition products determined experimentally. The two proposed potential conversion reactions are shown in eqs 1 and 2:

$$
\begin{aligned}
& \mathrm{Li}+\mathrm{CH}_{3} \mathrm{NH}_{3} \mathrm{PbX}_{3} \rightarrow \mathrm{CH}_{3} \mathrm{NH}_{3} \mathrm{X}+\mathrm{LiPbX}_{2} \\
& 2 \mathrm{Li}+\mathrm{CH}_{3} \mathrm{NH}_{3} \mathrm{PbX}_{3} \rightarrow \mathrm{CH}_{3} \mathrm{NH}_{3} \mathrm{X}+2 \mathrm{LiX}+\mathrm{Pb}
\end{aligned}
$$

The conversion reaction given by eq 1 involves phase separation (decomposition) of the perovskite, with $\mathrm{Li}$ effectively being intercalated in the $\mathrm{PbX}_{2}$ structure. Phase separation is often an issue for these materials and has even been reported to be exothermic for the room-temperature tetragonal structure of $\mathrm{CH}_{3} \mathrm{NH}_{3} \mathrm{PbI}_{3}$. Similar conversion pathways (without $\mathrm{Li}$ ) have been proposed based on the influence of oxygen and moisture on $\mathrm{CH}_{3} \mathrm{NH}_{3} \mathrm{PbI}_{3}$.

An alternative conversion reaction (eq 2) also involves the formation of $\mathrm{CH}_{3} \mathrm{NH}_{3} \mathrm{X}$, but with the addition of $\mathrm{LiX}$ and $\mathrm{Pb}$ metal as products. A recent investigation has highlighted the importance of redox chemistry in the decomposition of hybrid halide perovskites in optoelectronic devices. ${ }^{52}$ In the report by Zhao et al., ${ }^{52}$ the $\mathrm{Pb}^{2+}$ ion of $\mathrm{CH}_{3} \mathrm{NH}_{3} \mathrm{PbI}_{3}$ is rapidly reduced to $\mathrm{Pb}^{0}$ by intrinsic interfacial interactions with an $\mathrm{Al}$ electrode in their device architecture, not dissimilar to the effect of $\mathrm{Li}$ observed in this work. The conversion reaction in eq 2 is similar to reactions found in traditional battery materials, ${ }^{57-59}$ where the cation of a metal oxide or fluoride is reduced by Li metal to form the corresponding metal and lithium oxide/fluoride (e.g., $\left.\mathrm{CoO}+2 \mathrm{Li} \rightarrow \mathrm{Co}+\mathrm{Li}_{2} \mathrm{O}\right)$. We certainly do not rule out the existence of further reaction steps, for instance, the breakdown of $\mathrm{CH}_{3} \mathrm{NH}_{3} \mathrm{I}$ to $\mathrm{HI}$ and $\mathrm{CH}_{3} \mathrm{NH}_{2}$ or the formation of $\mathrm{NH}_{3}$ and $\mathrm{CH}_{3} \mathrm{I}$ gases, after these initial potential pathways.

The energies for these two reaction pathways for each perovskite material are summarized in Figure 6. All conversion reaction energies (eqs 1 and 2) are for full $\mathrm{Li}$ intercalation $(x \mathrm{Li}$ $=1.0$ ). Two main points emerge from these results. First, the proposed reactions for each perovskite are exothermic, indicating that conversion is favorable. Second, the most favorable energies are calculated for eq 2 and are larger than any of the values calculated for $\mathrm{Li}$ intercalation at any concentration. Our results strongly suggest that conversion to form $\mathrm{CH}_{3} \mathrm{NH}_{3} \mathrm{X}, \mathrm{LiX}$, and $\mathrm{Pb}$ is the dominant mechanism in these systems, as opposed to $\mathrm{Li}$ intercalation. This is consistent with PXRD results in which bromide perovskite peaks are no longer present and new $\mathrm{Pb}$ metal peaks are observed. The trends indicate that the conversion becomes more favorable with decreasing anion size. These results help to explain why such significantly distorted structures were found for $\mathrm{LiCH}_{3} \mathrm{NH}_{3} \mathrm{PbBr}_{3}$ and $\mathrm{LiCH}_{3} \mathrm{NH}_{3} \mathrm{PbCl}_{3}$. The formation of

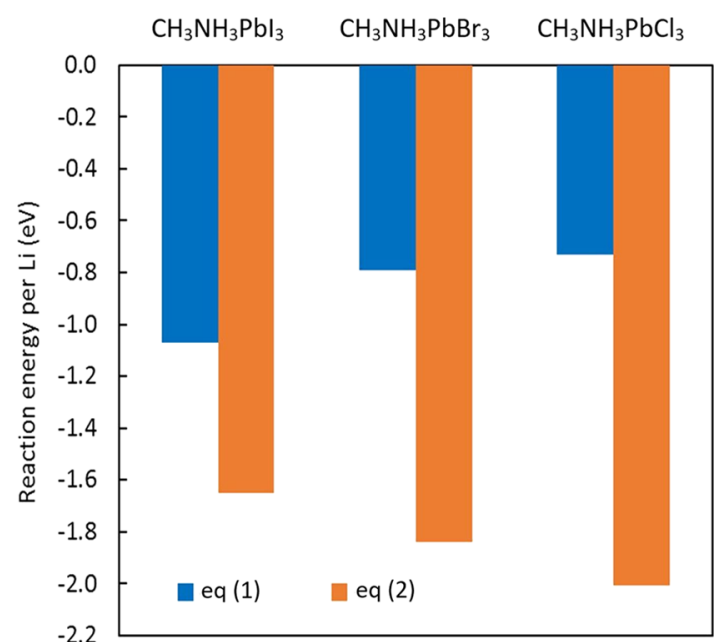

Figure 6. Calculated energies for the conversion reactions (eqs 1 and 2) for $\mathrm{CH}_{3} \mathrm{NH}_{3} \mathrm{PbX}_{3}$.

stable lithium halides is also likely to be a key factor for the favorable energies of eq 2.

In conclusion, this combined computational-experimental study has examined $\mathrm{Li}$ intercalation and conversion mechanisms in a series of organic-inorganic halide perovskites, $\mathrm{CH}_{3} \mathrm{NH}_{3} \mathrm{PbI}_{3}, \mathrm{CH}_{3} \mathrm{NH}_{3} \mathrm{PbBr}_{3}$, and $\mathrm{CH}_{3} \mathrm{NH}_{3} \mathrm{PbCl}_{3}$. A conversion process with the production of $\mathrm{CH}_{3} \mathrm{NH}_{3} \mathrm{X}$, lithium halides ( $\mathrm{LiX}$ ), and $\mathrm{Pb}$ metal is found to be strongly exothermic for all three perovskites and more energetically favorable than $\mathrm{Li}$ intercalation. Electrochemical and PXRD measurements also support the conclusion that conversion reactions are likely to take place in $\mathrm{CH}_{3} \mathrm{NH}_{3} \mathrm{PbBr}_{3}$. Our results help to rationalize the experimentally observed differences in lithium intercalation behavior for these materials and especially the poor electrochemical performance of $\mathrm{CH}_{3} \mathrm{NH}_{3} \mathrm{PbI}_{3}$.

This work provides the first detailed study of the atomic scale mechanisms of Li reactions with hybrid halide perovskites, with important implications for their potential energy storage applications.

\section{ASSOCIATED CONTENT}

\section{Supporting Information}

The Supporting Information is available free of charge on the ACS Publications website at DOI: 10.1021/acsenergylett.7b00437.

Computational and experimental details, intercalation voltages and Bader charge analysis for $\mathrm{LiCH}_{3} \mathrm{NH}_{3} \mathrm{PbI}_{3}$ with the inclusion of SOC and vdW effects, interatomic distances and optimized structures for $\mathrm{Li}$ octahedra in $\mathrm{LiCH}_{3} \mathrm{NH}_{3} \mathrm{PbX}_{3}$, and $\mathrm{Li}$ intercalation energies and structures for the three primary $\mathrm{CH}_{3} \mathrm{NH}_{3}{ }^{+}$orientations (PDF)

\section{AUTHOR INFORMATION}

\section{Corresponding Authors}

*E-mail: j.a.dawson@bath.ac.uk (J.A.D.).

*E-mail: m.s.islam@bath.ac.uk (M.S.I.).

ORCID

Christopher Eames: 0000-0002-5548-2655

M. Saiful Islam: 0000-0003-3882-0285 


\section{Notes}

The authors declare no competing financial interest.

\section{ACKNOWLEDGMENTS}

The authors gratefully acknowledge the EPSRC Programme Grant "Enabling next generation lithium batteries" (EP/ M009521/0) and the MCC/Archer consortium (EP/ L000202/1). P.G.B. and M.S.I are indebted to the EPSRC SUPERGEN for financial support, including the Supergen Energy Storage grant. We thank Dr. Giles Eperon for useful discussions.

\section{REFERENCES}

(1) Zhang, W.; Eperon, G. E.; Snaith, H. J. Metal Halide Perovskites for Energy Applications. Nat. Energy 2016, 1, 16048.

(2) Green, M. A.; Ho-Baillie, A.; Snaith, H. J. The Emergence of Perovskite Solar Cells. Nat. Photonics 2014, 8, 506-514.

(3) Graetzel, M. The Light and Shade of Perovskite Solar Cells. Nat. Mater. 2014, 13, 838-842.

(4) Kojima, A.; Teshima, K.; Shirai, Y.; Miyasaka, T. Organometal Halide Perovskites as Visible-Light Sensitizers for Photovoltaic Cells. J. Am. Chem. Soc. 2009, 131, 6050-6051.

(5) Wang, Z.; McMeekin, D. P.; Sakai, N.; van Reenen, S.; Wojciechowski, K.; Patel, J. B.; Johnston, M. B.; Snaith, H. J. Efficient and Air-Stable Mixed-Cation Lead Mixed-Halide Perovskite Solar Cells with n-Doped Organic Electron Extraction Layers. Adv. Mater. 2017, 29, 1604186.

(6) Saliba, M.; Matsui, T.; Domanski, K.; Seo, J.-Y.; Ummadisingu, A.; Zakeeruddin, S. M.; Correa-Baena, J.-P.; Tress, W. R.; Abate, A.; Hagfeldt, A.; Graetzel, M. Incorporation of Rubidium Cations into Perovskite Solar Cells Improves Photovoltaic Performance. Science 2016, 354, 206.

(7) Brenner, T. M.; Egger, D. A.; Kronik, L.; Hodes, G.; Cahen, D. Hybrid Organic-Inorganic Perovskites: Low-Cost Semiconductors with Intriguing Charge-Transport Properties. Nat. Rev. Mater. 2016, $1,15007$.

(8) Burschka, J.; Pellet, N.; Moon, S.-J.; Humphry-Baker, R.; Gao, P.; Nazeeruddin, M. K.; Grätzel, M. Sequential Deposition as a Route to High-Performance Perovskite-Sensitized Solar Cells. Nature 2013, 499, 316-319.

(9) Lee, M. M.; Teuscher, J.; Miyasaka, T.; Murakami, T. N.; Snaith, H. J. Efficient Hybrid Solar Cells Based on Meso-Superstructured Organometal Halide Perovskites. Science 2012, 338, 643-647.

(10) Xing, G.; Mathews, N.; Sun, S.; Lim, S. S.; Lam, Y. M.; Grätzel, M.; Mhaisalkar, S.; Sum, T. C. Long-Range Balanced Electron- and Hole-Transport Lengths in Organic-Inorganic $\mathrm{CH}_{3} \mathrm{NH}_{3} \mathrm{PbI}_{3}$. Science 2013, 342, 344-347.

(11) Xiao, Z.; Yuan, Y.; Shao, Y.; Wang, Q.; Dong, Q.; Bi, C.; Sharma, P.; Gruverman, A.; Huang, J. Giant Switchable Photovoltaic Effect in Organometal Trihalide Perovskite Devices. Nat. Mater. 2014, 14, 193-198.

(12) Zhou, H. P.; Chen, Q.; Li, G.; Luo, S.; Song, T.-B.; Duan, H.-S.; Hong, Z.; You, J.; Liu, Y.; Yang, Y. Interface Engineering of Highly Efficient Perovskite Solar Cells. Science 2014, 345, 542-546.

(13) Jeon, N. J.; Noh, J. H.; Kim, Y. C.; Yang, W. S.; Ryu, S.; Seok, S. I. Solvent Engineering for High-Performance Inorganic-Organic Hybrid Perovskite Solar Cells. Nat. Mater. 2014, 13, 897-903.

(14) Johnston, M. B.; Herz, L. M. Hybrid Perovskites for Photovoltaics: Charge-Carrier Recombination, Diffusion, and Radiative Efficiencies. Acc. Chem. Res. 2016, 49, 146-154.

(15) Stoumpos, C. C.; Malliakas, C. D.; Kanatzidis, M. G. Semiconducting Tin and Lead Iodide Perovskites with Organic Cations: Phase Transitions, High Mobilities, and Near-Infrared Photoluminescent Properties. Inorg. Chem. 2013, 52, 9019-9038.

(16) Xia, H.-R.; Sun, W.-T; Peng, L.-M. Hydrothermal Synthesis of Organometal Halide Perovskites for Li-Ion Batteries. Chem. Commun. 2015, 51, 13787-13790.
(17) Smith, I. C.; Smith, M. D.; Jaffe, A.; Lin, Y.; Karunadasa, H. I. Between the Sheets: Postsynthetic Transformations in Hybrid Perovskites. Chem. Mater. 2017, 29, 1868-1884.

(18) Vicente, N.; Garcia-Belmonte, G. Methylammonium Lead Bromide Perovskite Battery Anodes Reversibly Host High Li-Ion Concentrations. J. Phys. Chem. Lett. 2017, 8, 1371-1374.

(19) Jaffe, A.; Karunadasa, H. I. Lithium Cycling in a Self-Assembled Copper Chloride-Polyether Hybrid Electrode. Inorg. Chem. 2014, 53, 6494-6496.

(20) Jiang, Q.; Chen, M.; Li, J.; Wang, M.; Zeng, X.; Besara, T.; Lu, J.; Xin, Y.; Shan, X.; Pan, B.; Wang, C.; Lin, S.; Siegrist, T.; Xiao, Q.; $\mathrm{Yu}, \mathrm{Z}$. Electrochemical Doping of Halide Perovskites with Ion Intercalation. ACS Nano 2017, 11, 1073-1079.

(21) Inaguma, Y.; Liquan, C.; Itoh, M.; Nakamura, T.; et al. High Ionic Conductivity in Lithium Lanthanum Titanate. Solid State Commun. 1993, 86, 689-693.

(22) Stramare, S.; Thangadurai, V.; Weppner, W. Lithium Lanthanum Titanates: A Review. Chem. Mater. 2003, 15, 3974-3990.

(23) Islam, M. S.; Fisher, C. A. J. Lithium and Sodium Battery Cathode Materials: Computational Insights into Voltage, Diffusion and Nanostructural Properties. Chem. Soc. Rev. 2014, 43, 185-204.

(24) Yuan, Y.; Zhan, C.; He, K.; Chen, H.; Yao, W.; Sharifi-Asl, S.; Song, B.; Yang, Z.; Nie, A.; Luo, X.; et al. The Influence of Large Cations on the Electrochemical Properties of Tunnel-Structured Metal Oxides. Nat. Commun. 2016, 7, 13374.

(25) Armstrong, A. R.; Lyness, C.; Panchmatia, P. M.; Islam, M. S.; Bruce, P. G. The Lithium Intercalation Process in the Low-Voltage Lithium Battery Anode $\mathrm{Li}_{1+x} \mathrm{~V}_{1-x} \mathrm{O}_{2}$. Nat. Mater. 2011, 10, 223-229.

(26) Dawson, J. A.; Tanaka, I. Li Intercalation into a $\beta-\mathrm{MnO}_{2}$ Grain Boundary. ACS Appl. Mater. Interfaces 2015, 7, 8125-8131.

(27) Dawson, J. A.; Robertson, J. Improved Calculation of $\mathrm{Li}$ and $\mathrm{Na}$ Intercalation Properties in Anatase, Rutile, and $\mathrm{TiO}_{2}(\mathrm{~B})$. J. Phys. Chem. C 2016, 120, 22910-22917.

(28) Seo, D.-H.; Lee, J.; Urban, A.; Malik, R.; Kang, S.; Ceder, G. The Structural and Chemical Origin of the Oxygen Redox Activity in Layered and Cation-Disordered Li-Excess Cathode Materials. Nat. Chem. 2016, 8, 692-697.

(29) Jain, A.; Shin, Y.; Persson, K. A. Computational Predictions of Energy Materials using Density Functional Theory. Nat. Rev. Mater. 2016, 1, 15004.

(30) Eames, C.; Frost, J. M.; Barnes, P. R. F.; O’Regan, B. C.; Walsh, A.; Islam, M. S. Ionic Transport in Hybrid Lead Iodide Perovskite Solar Cells. Nat. Commun. 2015, 6, 7497.

(31) Frost, J. M.; Butler, K. T.; Brivio, F.; Hendon, C. H.; van Schilfgaarde, M.; Walsh, A. Atomistic Origins of High-Performance in Hybrid Halide Perovskite Solar Cells. Nano Lett. 2014, 14, 25842590.

(32) Aristidou, N.; Eames, C.; Islam, M. S.; Haque, S. A.; et al. Fast Oxygen Diffusion and Iodide Defects Mediate Oxygen-Induced Degradation of Perovskite Solar Cells. Nat. Commun. 2017, 8, 15218.

(33) Azpiroz, J. M.; Mosconi, E.; Bisquert, J.; De Angelis, F. Defect Migration in Methylammonium Lead Iodide and its Role in Perovskite Solar Cell Operation. Energy Environ. Sci. 2015, 8, 2118-2127.

(34) Long, R.; Liu, J.; Prezhdo, O. V. Unravelling the Effects of Grain Boundary and Chemical Doping on Electron-Hole Recombination in $\mathrm{CH}_{3} \mathrm{NH}_{3} \mathrm{PbI}_{3}$ Perovskite by Time-Domain Atomistic Simulation. J. Am. Chem. Soc. 2016, 138, 3884-3890.

(35) Brivio, F.; Walker, A. B.; Walsh, A. Structural and Electronic Properties of Hybrid Perovskites for High-Efficiency Thin-Film Photovoltaics from First-Principles. APL Mater. 2013, 1, 042111.

(36) Frost, J. M.; Butler, K. T.; Walsh, A. Molecular Ferroelectric Contributions to Anomalous Hysteresis in Hybrid Perovskite Solar Cells. APL Mater. 2014, 2, 081506.

(37) Kresse, G.; Furthmüller, J. Efficient Iterative Schemes for $\mathrm{Ab}$ Initio Total-Energy Calculations using a Plane-Wave Basis Set. Phys. Rev. B: Condens. Matter Mater. Phys. 1996, 54, 11169-11186.

(38) Perdew, J. P.; Ruzsinszky, A.; Csonka, G. I.; Vydrov, O. A.; Scuseria, G. E.; Constantin, L. A.; Zhou, X.; Burke, K. Restoring the 
Density-Gradient Expansion for Exchange in Solids and Surfaces. Phys. Rev. Lett. 2008, 100, 136406.

(39) Baikie, T.; Barrow, N. S.; Fang, Y.; Keenan, P. J.; Slater, P. R.; Piltz, R. O.; Gutmann, M.; Mhaisalkar, S. G.; White, T. J. A Combined Single Crystal Neutron/X-Ray Diffraction and Solid-State Nuclear Magnetic Resonance Study of the Hybrid Perovskites $\mathrm{CH}_{3} \mathrm{NH}_{3} \mathrm{PbX}_{3}$ (X = I, Br and Cl). J. Mater. Chem. A 2015, 3, 9298-9307.

(40) Mosconi, E.; De Angelis, F. Mobile Ions in Organohalide Perovskites: Interplay of Electronic Structure and Dynamics. ACS Energy Lett. 2016, 1, 182-188.

(41) Ong, K. P.; Goh, T. W.; Xu, Q.; Huan, A. Mechanical Origin of the Structural Phase Transition in Methylammonium Lead Iodide $\mathrm{CH}_{3} \mathrm{NH}_{3} \mathrm{PbI}_{3}$. J. Phys. Chem. Lett. 2015, 6, 681-685.

(42) Quarti, C.; Mosconi, E.; Ball, J. M.; D’Innocenzo, V.; Tao, C.; Pathak, S.; Snaith, H. J.; Petrozza, A.; De Angelis, F. Structural and Optical Properties of Methylammonium Lead Iodide Across the Tetragonal to Cubic Phase Transition: Implications for Perovskite Solar Cells. Energy Environ. Sci. 2016, 9, 155-163.

(43) Leguy, A. M. A.; Frost, J. M.; McMahon, A. P.; Sakai, V. G.; Kochelmann, W.; Law, C.; Li, X.; Foglia, F.; Walsh, A.; O'Regan, B. C.; Nelson, J.; Cabral, J. T.; Barnes, P. R. F. The Dynamics of Methylammonium Ions in Hybrid Organic-Inorganic Perovskite Solar Cells. Nat. Commun. 2015, 6, 7124.

(44) Motta, C.; El-Mellouhi, F.; Kais, S.; Tabet, N.; Alharbi, F.; Sanvito, S. Revealing the Role of Organic Cations in Hybrid Halide Perovskite $\mathrm{CH}_{3} \mathrm{NH}_{3} \mathrm{PbI}_{3}$. Nat. Commun. 2015, 6, 7026.

(45) Saidaminov, M. I.; Abdelhady, A. L.; Murali, B.; Alarousu, E.; Burlakov, V. M.; Peng, W.; Dursun, I.; Wang, L.; He, Y.; Maculan, G.; Goriely, A.; Wu, T.; Mohammed, O.; Bakr, O. M. High-Quality Bulk Hybrid Perovskite Single Crystals Within Minutes by Inverse Temperature Crystallization. Nat. Commun. 2015, 6, 7586.

(46) Henkelman, G.; Arnaldsson, A.; Jónsson, H. A Fast and Robust Algorithm for Bader Decomposition of Charge Density. Comput. Mater. Sci. 2006, 36, 354-360.

(47) Melot, B. C.; Scanlon, D. O.; Reynaud, M.; Rousse, G.; Chotard, J.-N.; Henry, M.; Tarascon, J.-M. Chemical and Structural Indicators for Large Redox Potentials in Fe-Based Positive Electrode Materials. ACS Appl. Mater. Interfaces 2014, 6, 10832-10839.

(48) Xu, S.; Jacobs, R. M.; Nguyen, H. M.; Hao, S.; Mahanthappa, M.; Wolverton, C.; Morgan, D. Lithium Transport Through LithiumIon Battery Cathode Coatings. J. Mater. Chem. A 2015, 3, 1724817272.

(49) Verma, P.; Maire, P.; Novák, P. A Review of the Features and Analyses of the Solid Electrolyte Interphase in Li-Ion Batteries. Electrochim. Acta 2010, 55, 6332-6341.

(50) Jaffe, A.; Lin, Y.; Beavers, C. M.; Voss, J.; Mao, W. L.; Karunadasa, H. I. High-Pressure Single-Crystal Structures of 3D LeadHalide Hybrid Perovskites and Pressure Effects on their Electronic and Optical Properties. ACS Cent. Sci. 2016, 2, 201-209.

(51) Swanson, H. E.; Tatge, E. Standard X-ray diffraction powder patterns. Vol. I, Data for 54 inorganic substances; National Bureau of Standards: Washington, DC, 1953; Vol. 539; pp 1-95.

(52) Zhao, L.; Kerner, R. A.; Xiao, Z.; Lin, Y. L.; Lee, K. M.; Schwartz, J.; Rand, B. P. Redox Chemistry Dominates the Degradation and Decomposition of Metal Halide Perovskite Optoelectronic Devices. ACS Energy Lett. 2016, 1, 595-602.

(53) Christians, J. A.; Miranda Herrera, P. A.; Kamat, P. V. Transformation of the Excited State and Photovoltaic Efficiency of $\mathrm{CH}_{3} \mathrm{NH}_{3} \mathrm{PbI}_{3}$ Perovskite upon Controlled Exposure to Humidified Air. J. Am. Chem. Soc. 2015, 137, 1530-1538.

(54) Berhe, T. A.; Su, W.-N.; Chen, C.-H.; Pan, C.-J.; Cheng, J.-H.; Chen, H.-M.; Tsai, M.-C.; Chen, L.-Y.; Dubale, A. A.; Hwang, B.-J. Organometal Halide Perovskite Solar Cells: Degradation and Stability. Energy Environ. Sci. 2016, 9, 323-356.

(55) Leguy, A. M. A.; Hu, Y.; Campoy-Quiles, M.; Alonso, M. I.; Weber, O. J.; Azarhoosh, P.; van Schilfgaarde, M.; Weller, M. T.; Bein, T.; Nelson, J.; Docampo, P.; Barnes, P. R. F. Reversible Hydration of $\mathrm{CH}_{3} \mathrm{NH}_{3} \mathrm{PbI}_{3}$ in Films, Single Crystals, and Solar Cells. Chem. Mater. 2015, 27, 3397-3407.
(56) Ahn, N.; Kwak, K.; Jang, M. S.; Yoon, H.; Lee, B. Y.; Lee, J.-K.; Pikhitsa, P. V.; Byun, J.; Choi, M. Trapped Charge-Driven Degradation of Perovskite Solar Cells. Nat. Commun. 2016, 7, 13422.

(57) Tarascon, J.-M.; Poizot, P.; Laruelle, S.; Grugeon, S.; Dupont, L. Nano-Sized Transition-Metal Oxides as Negative-Electrode Materials for Lithium-Ion Batteries. Nature 2000, 407, 496-499.

(58) Cabana, J.; Monconduit, L.; Larcher, D.; Palacín, M. R. Beyond Intercalation-Based Li-Ion Batteries: The State of the Art and Challenges of Electrode Materials Reacting Through Conversion Reactions. Adv. Mater. 2010, 22, E170-E192.

(59) Wang, F.; Robert, R.; Chernova, N. A.; Pereira, N.; Omenya, F.; Badway, F.; Hua, X.; Ruotolo, M.; Zhang, R.; Wu, L.; et al. Conversion Reaction Mechanisms in Lithium Ion Batteries: Study of the Binary Metal Fluoride Electrodes. J. Am. Chem. Soc. 2011, 133, 18828-18836. 